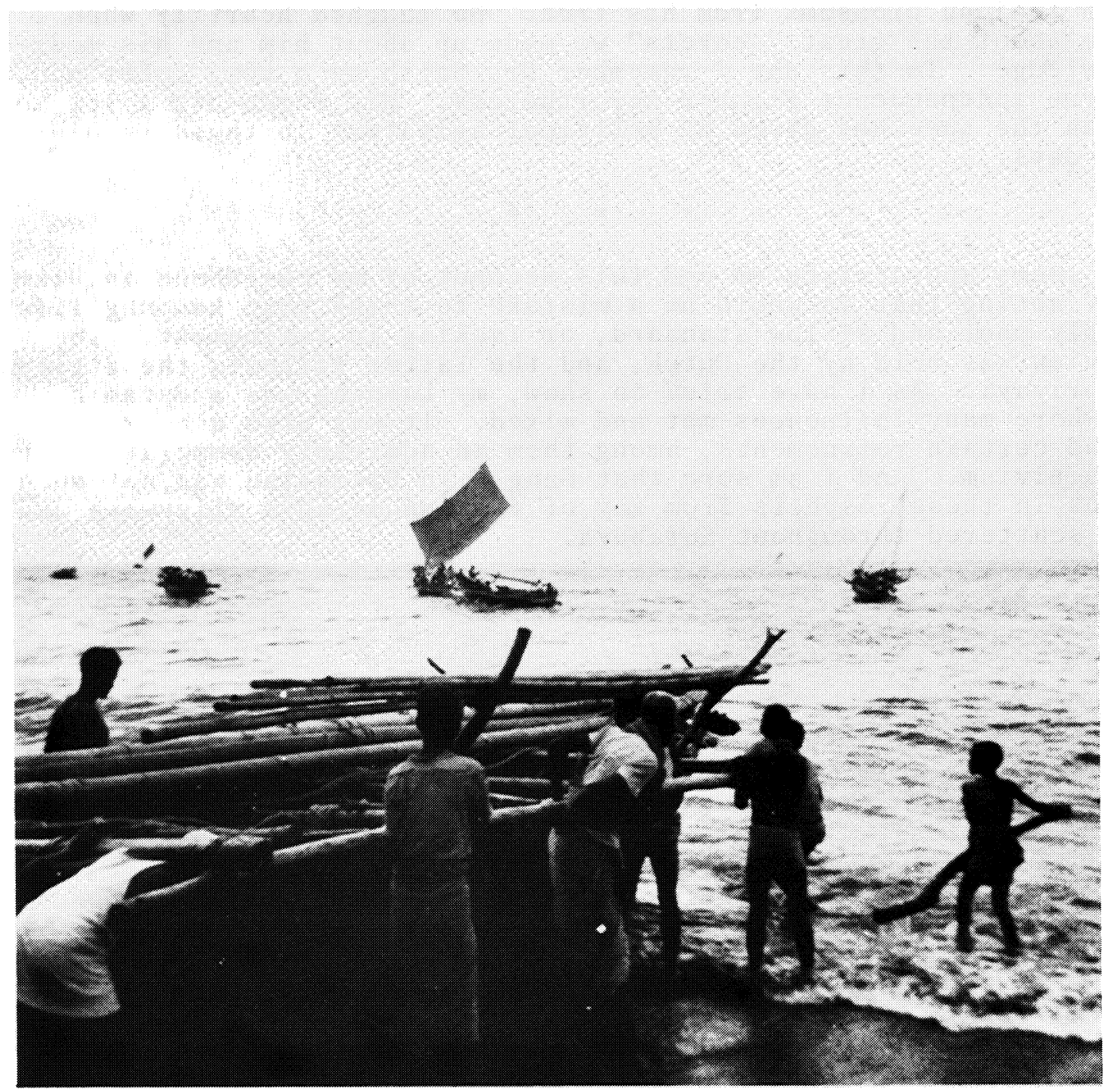

Photograph I 


\title{
LAMALERAP: A WHALING VILLAGE IN EASTERN INDONESIA
}

\author{
R. H. Barnes
}

\begin{abstract}
Was it not so, 0 Timor Tom! thou famed Leviathan, scarred like an iceberg, who so long did'st lurk in the Oriental straits of that name, whose spout was oft seen from the palmy beach of Ombay?
\end{abstract}

Melville, Moby Dick

The Timor Straits have borne vessels trafficking in the colorful and historic ventures of many periods in human navigation. Anciently, sandalwood from the island of Timor found its way, in all probability, to markets in China. The same product later attracted Arab, and Makasarese, Portuguese and Dutch traders and fleets. Local traditions allude to the navies of the ancient Javanese empire of Madjapahit or the political influence of the spice kingdom of Ternate. Magellan's Victoria sailed through the Timor Straits on its journey around the globe, as did many subsequent expeditions of discovery, exploration, commerce or conquest. It was a recognized hunting-ground on the schedules of nineteenth-century British and American whaling voyages, and modern commerce still uses it as a sea lane to Australia and the Western Pacific.

Among those who go out upon its waters in search of 1 ivelihood are the expert boatmen, fishermen and hunters of large sea mammals from two villages, Lamakera and Lamalerap, located respectively on the shores of the small Indonesian islands of Solor and Lembata. Since at least 1836 there have been notices of the fact that these villages take whale of various species, and it has often been thought, probably erroneously, that they are the only two whaling villages in Indonesia. Brief descriptions of the local whale-hunt have been published from time to time, but evidently none by eyewitnesses. Until recently, neither village had been visited by a professional ethnographer other than Ernst Vatter, who made a brief excursion through the area in 1929. An industry of this nature, demanding such daring and skill from its practitioners, should be of general interest, beyond the problems and enticements which the local cultures present to the professional social anthropologist. Yet the opportunity to observe this industry with its traditions intact still exists, despite many changes in the cultures, though with the threatened extinction of many species of whale, this opportunity may not last much longer. No comprehensive accounts have been made, nor can be produced on the basis of the few scanty published reports of Lamakera and Lamalerap; yet it would be very useful to put on record something about this almost unique aspect of contemporary Indonesian society, both for a public with a general interest in the nation and for professionals concerned with certain themes in structural anthropology, for which their societies provide excellent practical examples. 
I had the good fortune to visit the village of Lamalerap for a week, during a break in research elsewhere on the island of Lembata, 1 and in the course of this stay, on July 17, 1970, I was a guest in the boat Mĕnula Bĕlolong, belonging to the clan Lamakera. My intention here is to provide a description of the hunt and capture of whale in which I took part on this occasion, and to give some brief accounting of the society and culture of Lamalerap. I do not intend to record all my observations from the week in Lamalerap now, for I plan at some time to return to the village for several months of intensive research. It might be thought best to wait until that work is done before making anything available, but the primary object of this paper--an eyewitness account of the capture of a whale, together with the first photographs of the hunt--is of such singular interest that it seems to justify presentation in this preliminary form.

Solor and Lembata (Lomblen) are two islands of the Solor Archipelago, a cluster of small volcanic islands 1 ying between Flores and Alor in eastern Indonesia. Except for Pantar, these islands (including East Flores) are inhabited by a culture which may be designated, after their own name for their language, the Lamaholot. ${ }^{2}$ The Lamaholot 1 anguage is divided into several mutually intelligible dialects, of which those on Lembata are the most numerous and most varied. ${ }^{3}$ Parts of the Lamaholot area have been under European influence from the middle of the sixteenth century when the Dominican order established a mission on Solor and, a little later, at Larantuka on Flores. From then on, at different periods, Portuguese or Dutch garrisons were established on Solor, and Lamakera was drawn into the disruptive and often bloody struggles of the colonial powers. By contrast, Lembata was rarely visited by Europeans until the last century and Lamalerap was almost wholly uninfluenced by outsiders in earlier centuries. This historical

1. Among the people of Kédang on the east end of Lembata. They are the only group on the island who do not speak a dialect of Lamaholot. See R. H. Barnes, Kêdang: A Study of the Collective Thought of an Indonesian People (Oxford: The Clarendon Press, in press). The research was sponsored by the Lembaga Ilmu Pengetahuan Indonesia and supported by a Graduate Fellowship from the National Science Foundation of the United States. I wish to thank Dr. James J. Fox for reading the manuscript.

2. See R. H. Barnes, "Solorese," in Frank M. LeBar (ed.), Ethnic Groups of Insular Southeast Asia (New Haven: Human Relations Area Files Press, 1972). A complete bibliography may be found in R. H. Barnes, "An Ethnographic Survey of Lomblen and Neighboring Islands, Eastern Indonesia" (B.Litt. thesis, Oxford University, 1968).

3. The dialect spoken by the villagers of Lamalerap is different from that of the other villages in the same area. They regard their dialect to be closest in vocabulary to that spoken in the Lewotolo region of Lembata (thus all the way across on the north side of the island), on Solor and in eastern Adonara. See Ernst Vatter, Ata Kiwan: unbekannte Bergvölker im tropischem Holland (Leipzig: Bibliographisches Institut, 1932), p. 275. Whereas Lamaholot dialects, including that of their closest neighbors, generally have a $v$ or $w$, this sound is regularly replaced in Lamalerap by an $f$. Their dialect is also distinguished by a melodious manner of pronunciation. The villagers of Lamalerap do not pronounce the final $p$ in that name; this is used only by their immediate neighbors. 
chance, as will be shown below, accounts for certain striking contrasts between the two otherwise closely related villages.

Most villages in the Lamaholot area, including Lamakera and Lamalerap, have a segmentary social order, based on clans and lineages ordered by a rule of patrilineal descent. In addition, all villages for which we have any information appear to have an ideology of asymmetric prescriptive marriage alliance and a corresponding relationship terminology. ${ }^{4}$

The clans of the latter village are entirely of outside origin. The village has barely a foothold on the land and its agriculture is limited to the inconsequential amount of crops which can be produced from the stony soil in the spaces between the houses. The greater part of its food is derived from the maize, rice, cassava and other agricultural products which it buys or trades from the mountain villages. This fact sets Lamalerap apart from most other Lamaholot villages, which are with few exceptions agricultural communities, usually situated at a distance from the sea, and possessing no traditional associations with it. Lamalerap's history and economic situation have put a premium on enterprise and diversity in the search for subsistence, and this diversity has been increased by the opportunities made available as a consequence of the arrival of the Catholic mission early in this century. The people of this village are remarkable for their unusual openness to nove1 experiences and ideas. Whereas at the beginning of the century, most of the village depended primarily on large-scale fishing for a living, now only a fraction--though in absolute terms still an appreciable number--1ive principally from the catch of porpoise, whale, shark, manta ray and sea turtle hunted in their large sailing vessels or pĕzédang.

No other village on the island (and few in the area) is so divorced from agriculture or depends so much on fishing, and their singular position suggests the need for some remarks about their history and present organization. The tenuous hold which Lamalerap has on the land is shown by the fact that the ritual office of lord of the land, Zefo $a$ lap, is in the hands of clans of another village, Lama Manuk, situated in the hills above it. In fact there are two leffo alap, whose territory divides the village approximately in half. The border was formerly marked by a small house (inak) at the middle point of the beach, dividing the large storage sheds for the boats into two fairly equal groups. Each lord of the 1and supervised the building of his half of the inak. Formerly, on the first day on which the boats went out at the beginning of the fishing season, two pieces of white cloth would be sewed together in this house, a procedure which would also be followed in a case of serious trouble in the village, thus indicating the spiritual wholeness of the community. The building has now been replaced by a small chapel, which, however, serves virtually the same purpose. The lord of the land has a claim to the head of a whale captured by a boat from his section of the village, though, in fact, this is rarely given to him. ${ }^{5}$ The reason that the holders of this

4. As I did not visit Lamakera, I can not verify these facts for that village independently of published reports. What I will have to say here will principally concern Lamalerap.

5. Though they are usually lax in meeting this obligation, sometimes when searching by means of augury for the cause of some misfortune, they may think of their 
office come from outside the village is that the first clans to settle in Lamalerap had to receive permission to do so from the village of Lama Manuk which already had prior possession of the area.

The first clan to come here was the clan Lohajong. Its three branches are now separate, intermarrying clans. When one of these clans builds a temple, someone from another clan must cut the throat of the animal offered for the occasion. The eldest clan provides this service for the other two. When the eldest clan itself builds a temple, the second clan kills the animal. The youngest clan, thus, has no occasion to provide this service. However, this clan holds the office of head of the village, and when the office of kakang (the name for a district head in the territories placed under the Radja of Larantuka by the Dutch) was introduced, it was given to a man from this youngest clan, Lefotukan. We may recognize in this pattern the common Indonesian division between spiritual authority and temporal responsibilities and an association in Lamalerap of the eldest clan with the former function and the youngest clan with the latter. These three clans came from the village of Lohajong on Solor. Their place of origin before settling in Lohajong was Lapan Batan, a place locally reputed to have existed in what is now the strait between Lembata and Pantar before it sank into the sea. Vatter ${ }^{6}$ says that they consider themselves to have come, before settling on Lapan Batan, from SinaDjawa, which he translates as Malacca. In fact, Sina-Djawa (meaning China-Java) is used in these islands for any area to the west.

Another prominent clan came, as indicated by its name, directly from Lamakera, the nearby fishing village on the eastern end of Solor. Its ultimate origin is the Maumere region of east-central Flores. Other clans came from Lapan Batan via Labala, the peninsula situated to the east of Lamalerap. One clan, Ata Kai (men of Kai) came from the Kai Islands.

I have no information on the histories of the other clans, but in any case this is not the place to give a detailed account of the matter. ${ }^{7}$ It is sufficient to show that the village of Lamalerap is made

neglect of this duty. They say if they do not give the head of whale to the lefo alap, he will curse the catch and they will get nothing. If they have a period in which they can get nothing, they then sit together and try to think of what they may have done wrong--perhaps someone has not been fair to someone else in dividing the fish. Whoever thinks he might be the cause then washes his mouth. Formerly, this was apparently done with blood; now they use holy water.

6. Ata Kiwan, p. 205.

7. My notes contain the names of nineteen separate clans or named lineages. The fairly complete list of relationship terms and characteristic genealogical specifications for them given me by the former Kakang of Lamalerap, shows the same form of asymmetric prescriptive alliance found throughout Lamaholot. At the level of the clan, the marriage ties seem no longer to preserve a unilateral pattern, but I was assured that formerly the elders of the village were quite concerned that such a pattern be maintained. The Kakang gave me, in fact, an internally coherent list of the marriage rules among the clans. According to his understanding the clans were divided into three sections, where any clan of one section was allowed to take women from any clan of one of the other two sections, but not from the second of these, which took women from his own. The list of rules he gave me reflects without contradiction this three-section system. It 
up of settlers of quite diverse origin and that there are close historical ties with Lamakera.

It has often been thought that Lamalerap and Lamakera are the only two whaling villages in Indonesia.8 However, Geurtjens reports the communal hunt of large game including sea cow, ray, turtle and sperm whale by the inhabitants of the Kai Islands, though at a later point he says that sperm whale are approached with diffidence and that, rather than join in such uneven battle, by preference the prople employ the axiom: "Do nothing to me, and I will do nothing to you."g Since the inhabitants of Lamakera are said to come from Seran, 10 it may be that the origin of the fishery and of the hunt of whale is to be sought in the Moluccas.

Unlike Lamakera, lamalerap was drawn into the European sphere of influence quite late--a fact which has led to surprising differences between the two villages. Despite the historical ties and economic similarity between the two villages, Lamakera is entirely Moslem and belongs to the group called Padji, which in the Lamaholot area stands in traditional hostility to the group called Demong. II It was accordingly placed by the Dutch in this century under the control of the Radja of Adonara. Lamalerap on the other hand is now entirely Catholic, is regarded as Demong and was placed under the Radja of Larantuka.

The Dominican mission was established at Lohajong on Solor in $1561 ; 12$ and Lamakera was reported to contain 2000 Christians by 1598 . But in that year it became involved in an uprising against the Portuguese in the fort at Lohajong. The next year the portuguese destroyed the village by fire and sword.13 It recovered and became a completely Moslem village, which it has remained to this day. In league with the Radja of Lohajong, the Dutch under Appollonius Scotte took the Portuguese fort on Solor in 1613 and then signed a treaty with the Moslem

would take the collection of extensive genealogies to show whether there was ever a unidirectional exchange of women at any level, but the fact that the people of Lamalerap think of their social order in these terms is enough to show that the question of section systems does have a place in the consideration of asymmetric alliance.

8. Max Weber, "Iets over Walvischvangst in den Indischen Archipel," Rumphius Gedenboek (Haarlem: Koloniaal Museum te Haarlem, 1902), p. 91; "Walvischvangst in Nederlandsch-Indië," Tijdschrift voor Economische Geographie, I (1910), pp. 15658 ; Vatter, Ata Kiwan, p. 202.

9. H. Geurtjens, Uit een vreemde Worcld, of het Leven en Streven der Inlanders op de Kei-Eilanden ('s Hertogenbosch: Teulings, 1921), pp. 194, 280.

10. Cf. H. F.C. ten Kate, "Verslag eener Reis in de Timorgroep en Polynesië," Tijdschrift van het Konink1ijk Nederlandsch Aardrijskundig Genootschap, 2nd series, XI (1894), pp. 195-246, 333-90, 541-638,659-700,765-823. See especially, p. 238.

11. Paul Arndt, "Demon und Padzi, die feindlichen Brüder der Solor-Archipels," Anthropos, XXXIII (1938), pp. 1-58.

12. G. P. Rouffaer, "Chronologie der Dominikaner-Missie op Solor en Flores, vooral Poeloe Fnde, ca. 1556-1638; en Bibliographie over het Ende-Fort," NederlandschIndië Oud en Nieuw, VIII (1923-24), pp. 204-22, 256-60.

13. Ibid., p. 208. 
heads of Lohajong and Lamakera on Solor, and Lamahala, Trong and Adonara on Adonara. 14 These five villages formed an important part of the political make-up of the area from then on and often appear in treaties with the Dutch in the following centuries.

There is, it is true, a report of the martyring of a Catholic priest in Lamalerap on January $18,1621,15$ but otherwise this village never appears in the records until the nineteenth century and seems to have remained wholly uninfluenced by Christianity until 1886 when Dutch missionaries stationed in Larantuka began making regular visits. A permanent station was established first in 1920.16 According to Vatter's report, 17 nine years later the village had been made into an almost completely Christian settlement. The first missionary there achieved his ends by such flamboyant measures as cutting down sacred trees (as in Lewuka) or (in Lamalerap) burying the village altar under his new church. 18 The villagers report that he devoted his attention primarily to the elders, hoping to convert the village en masse through them--at which he was successful. A few years before his arrival, ceremonial cannibalism had been practiced in the village, and many villagers had preserved in public view the skulls of their ancestors. 19 The missionary buried these skulls, but some of the neighboring villages have managed to retain this old custom.

Lamalerap was the mission's first foothold on the island, and a government school was opened there in 1914. The villagers eagerly accepted the opportunities for education provided them by the government and above all by the mission, and for decades most of the school teachers on the island came from Lamalerap. Other members of the village received training as carpenters from the mission and that is one of the ways many now make their living. The village has additionally produced several Catholic priests, a journalist for a Jakarta newspaper and at least one doctor.

For administrative purposes Lamalerap is now divided into three separate villages, consisting of the two halves of the former structure and a new settlement to the east. Taken together the three number over 3000 inhabitants. The population lives from the sale or bartering of the products of both small- and large-scale fishing, the raising and selling of pigs, salt manufacture, the traditional industry of weaving and dyeing by the ikat process of fine sarongs which are sold on the island, and from incomes acquired as carpenters and school teachers. Although at one time they could sell their whale oil at Kupang on Timor, markets for their fishery are now found only on the island itself. When there is dried fish or whale meat to be sold, the women get up long before sunrise and walk many kilometers into the mountains hunting for opportunities to barter it in exchange for maize and cassava. In some periods of the year this can be an almost daily undertaking.

Whereas Christianity appears to have had a demoralizing impact on other villages, Lamalerap gives the impression of having made a success-

14. Ibid., p. 211 .

15. Ibid., p. 215.

16. Kurt Piskaty, "Perkembangan Geredja Katolik di Nusa Tenggara (Asia Tenggara) 1913-1963," in Piet Petu (ed.), Nusa Tenggara: Setengah Abad Karya Misi S.V.D. (Ende, Flores: Arnoldus Nusa Indah, 1966), p. 25.

17. Vatter, Ata Kiwan, p. 202.

18. Ibid., p. 206.

19. Ibid. 
ful adjustment to the confrontation. Almost all the land-based ceremonial has disappeared, but in that concerning the fishery on1y a smal1 amount has been lost and certain accommodations made, such as substituting holy water for chicken blood when aspersing the boats.

Each clan which participates in the hunt has its own boat or boats. These boats are kept in large boat sheds lined up along the beach, each boat having its own shed. According to one report, some clans used to keep the skulls of their ancestors on a platform at the back of these sheds. 20 On the first day of the season each year, this platform was taken down and the skulls were washed with seawater, rubbed with the skin of a coconut and then anointed with coconut oil. This procedure was intended to insure a good catch.

The hunt is, then, in the first instance a clan enterprise. The crew of each boat comes only from the clan which has built and owns that boat. Each boat is manned, I was told, by from seven to fourteen men. Disregarding a report by Kluppel 21 of twenty-four to thirty crewmen, which is impossible, the other published estimates range from six 22 to a high of sixteen. ${ }^{3}$ Thus, they are in reasonable agreement with those given me. The number depends upon the crewmen available on the day of the hunt. I was told that a boat would not go out if they could not get at least seven men, while they would not carry more than fourteen people in the boat at any time. When I went out, a place was made for me by leaving one crewman at home, so there were only thirteen crewmen and a passenger. A full crew consists of a helmsman, lama uri, a harpooner, lama $\mathrm{fa}$, and twelve meng. The latter term might be translated as oarsmen, but everyone rows when there is no other task. In addition to the crew must be added the téna alap. This might be translated "owner of the boat," but in fact it is an office, held by an old man in the clan, similar in nature to the familiar Indonesian "lord of the 1and." Téna alap would, then, be better translated "lord of the boat." He holds a position of primarily spiritual authority over the boat and the hunt, and for this reason he receives, although he does not go out on the hunt, a portion of the catch.

The season for fishing is from about May, toward the end of the rainy season, when the seas cease to be so rough and the sperm whale appear, until the coming of the rainy season in November. It is by no means devoted to whale alone, but the capture of a whale is always a great excitement and an important economic achievement. Given a favorable opportunity, they will always sacrifice the chance of taking any

20. See J. D. H. Beckering, "Beschrijving der Eilanden Adonara en Lomblen, behoorende tot de Solor-Groep," Tijdschrift van het Koninklijk Nederlandsch Aardrijkskungig Genootschap, 2nd series, XXVIII (1911), pp. 167-202, esp. p. 199 for confirmation by someone who saw them still in place.

21. J. M. Kluppe1, "De Solor-Eilanden," Tijdschrift voor Indische Taal-, Land- en Vo1kenkunde, XX (1873), pp. 378-98.

22. "Walvischvangst der Solorezen," Tijdschrift voor Nederlandsch Indië, XI, no. 2 (1849), pp. 66-67.

23. Vatter, Ata Kiwan, p. 204. 
other large game for an assault on whale. In a normal year the village may take some thirty of these animals. They had an exceptional season in 1969 and captured over sixty, but the next season until my visit had been very poor.

Contrary to an early report by Engbers, 24 they do not common $1 y$ follow their prey to Timor. A more accurate picture is given by Vatter 25 who telis us that a boat was once pulled to Timor by a whale, and that some children were named Kupang in memory of the event. This is still remembered and regarded as an extraordinary and, it goes without saying, exceptional incident. It is true that Kupang once offered a market for whale oil, but it no longer does so and there are no longer expeditions there to sell whale products.

I I I

The boat used in the large-scale fishery is called a pelédang, though the villagers almost always refer to it as téna, the common Lamaholot for "boat" in a general sense. Each boat is named and individualized in its decoration and in the particulars of its construction; and the same name and general features are kept when a boat is replaced or reconstructed. Thus, although the boat shown in Vatter's Plate 41 has certainly been replaced within forty years, members of the village to whom I showed the pictures immediately recognized which one it was.

The names are not painted on the boats, but nowadays they commonly paint slogans in Bahasa Indonesia, English or Latin on the bow and sides. At a moment in the hunt in which our boat had been rammed by three other boats caught up in tow of a runaway whale, the Nara Téna passed behind us and its slogan "God's will be done" flashed into view - a sentiment which seemed very much in place.

\section{Concerning their construction Vatter remarks:}

These "pledang" are not dug-outs but board boats whose construction presupposes a considerable technical ability and requires great care and time. Different types of wood are used for the individual planks and other parts of the boat, and the trees must be felled years before the construction is begun, so that the wood may completely dry out. Not a single nail is used anywhere in the boat, all the parts are joined with wooden pegs or rattan bindings. The planks of hard "hamsana" wood are not artificially bent, but are cut with the necessary curve out of the tree. The tools are an axe, a chisel ("laba") and a punch, "kĕtilo" of European origin. The craftsmen are called therefore "ata laba kĕtilo alap," that is, "Lords of the Chisel and Punch." The boat has two keels one over the other: a lower one of softer wood, which can be worn through from pulling the boat up the beach and then easily replaced, and a higher one of hard, well dried "kapapa"-wood. On it are set the abruptly upward pointing bow "manula" and the slanting, outward projecting stern "kole." The

24. E. Engbers, "Valvischvangers op het Eiland Lomblen," Berichten uit Nederlandsch Oost-Indië voor de Leden van den Sint-Claverbond, No. I (1906), pp. 9-13.

25. Ata Kiwan, p. 204. 
sides consist of six planks of different breadths and curves, laying one over the other, which are exactly fitted to each other with wooden pegs. There are ten crosspieces in all; over them lie the seats for the oarsmen....26

Each part and section of the boat has a name. (See Figures 1 and 2 for a partial representation.) The names of the inner sections of the boat often betray their use. The very first section, behind the bow, is called teka node, after a part of the crosspieces which divide the boat into sections (teka) and the two forked pieces (nodé) which form the rack for lances. In the second section or sera a thick rope called saba is kept. This rope is bent over the first section of the large hawser used when harpooning sperm whale. If the whale turns, then by looping this rope around the hawser, one can prevent its being pulled back through the boat, wreaking havoc to the rigging and men. For porpoise and ray there are two pegs on each side of the forward section which are strong enough to hold the lines used for this smaller game.

The third section is called the uma and takes its name from the drain hole found there. This drain hole must be located just to the right of the keel. I saw its location and confirmed its orientation when we were sailing back to land with our catch. I asked where it was, and to my alarm the man who was sitting next to it pulled out the plug, consisting of the skin of a coconut, and a stream of water shot high up into the boat. After that there was no longer any question.

The fourth section is the léo $u z i$, which means the "place of the Zéo," the rope used when harpooning manta ray. This is the only rope in the boat which is ceremonially fed on various occasions, and the only one which is taken out at the end of the season and stored in the boat house. When not in use it is coiled up in this section.

Behind the léo $u l i$ is the puang puka or "the trunk of the masts." It is in this section that the bases of the masts rest when the sail is hoisted. The center section of the boat is the fai mata or "eye of the water." Bilge water is bailed out here, which is why it has this name, which otherwise means "spring." Behind it is the befaleng, the section in which the befaleng or first part of the hawser used for whale is kept coiled. The second coil of this hawser or gĕlăfé is kept in the section of that name behind the befaleng. The next two sections are the semugur béla and the semugur keni, meaning large and small semugur; this word I cannot translate. Finally, the stern section is the lama uri tobo, or "the helmsman's seat."

The wood from which the boat is made must be put in so that the end which corresponds to the original trunk of the tree always lies toward the front of the boat. This is related to the common rule in this area whereby house posts must always be set into the ground in the same way in which they grew. The two mast poles of the boat, for instance, must when raised have their original trunk ends resting in the boat. A close study of similar rules in a neighboring society, Kédang, on the same island, shows that they are connected with cosmic notions and ideas about the flow of 1 ife force 27 and we can expect the same here. The bow of the boat is considered its head. The trunk-end then lies in conjunction with the head of the boat. The first or bow 

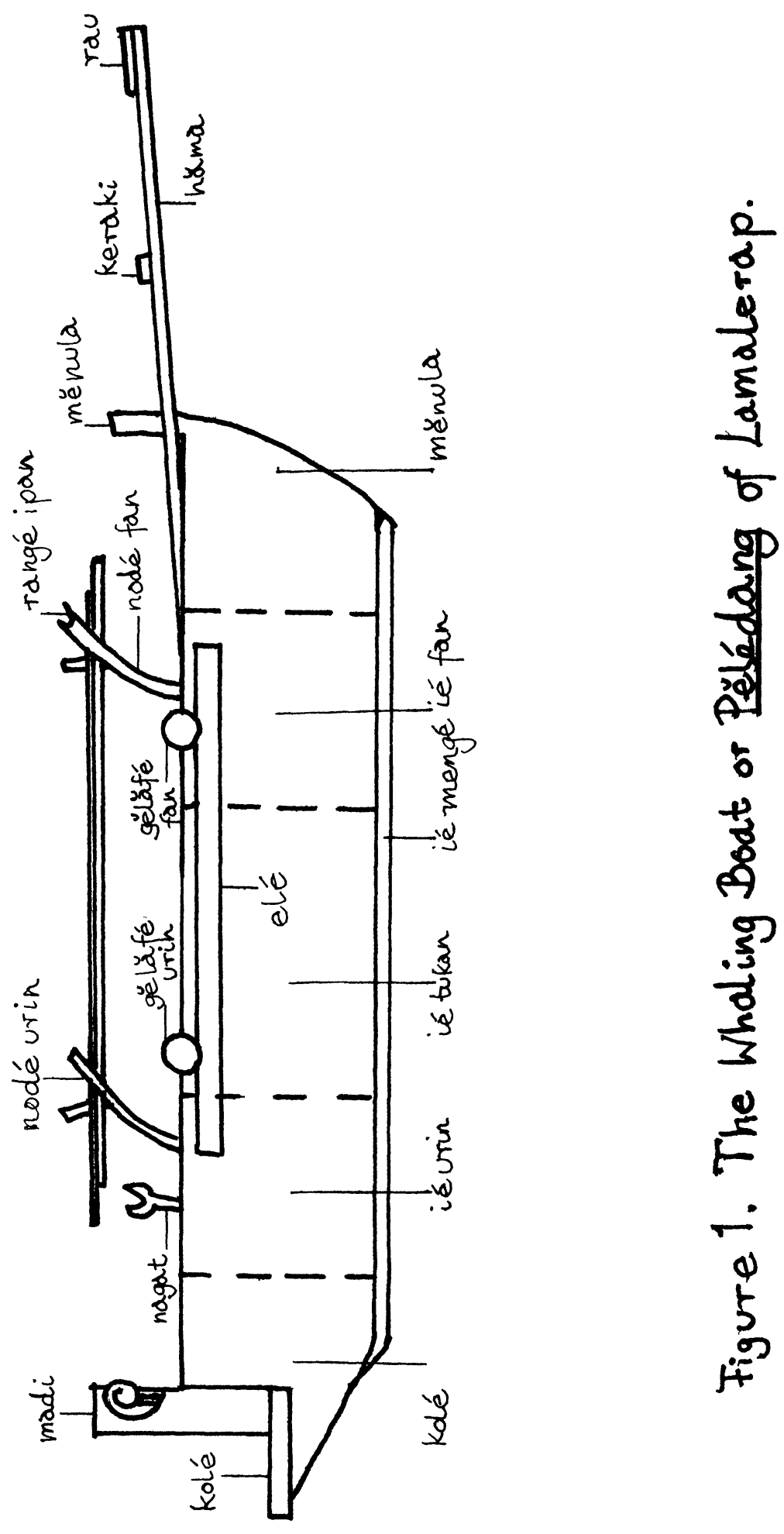

5

莡

疍

$\stackrel{0}{E}$

市 


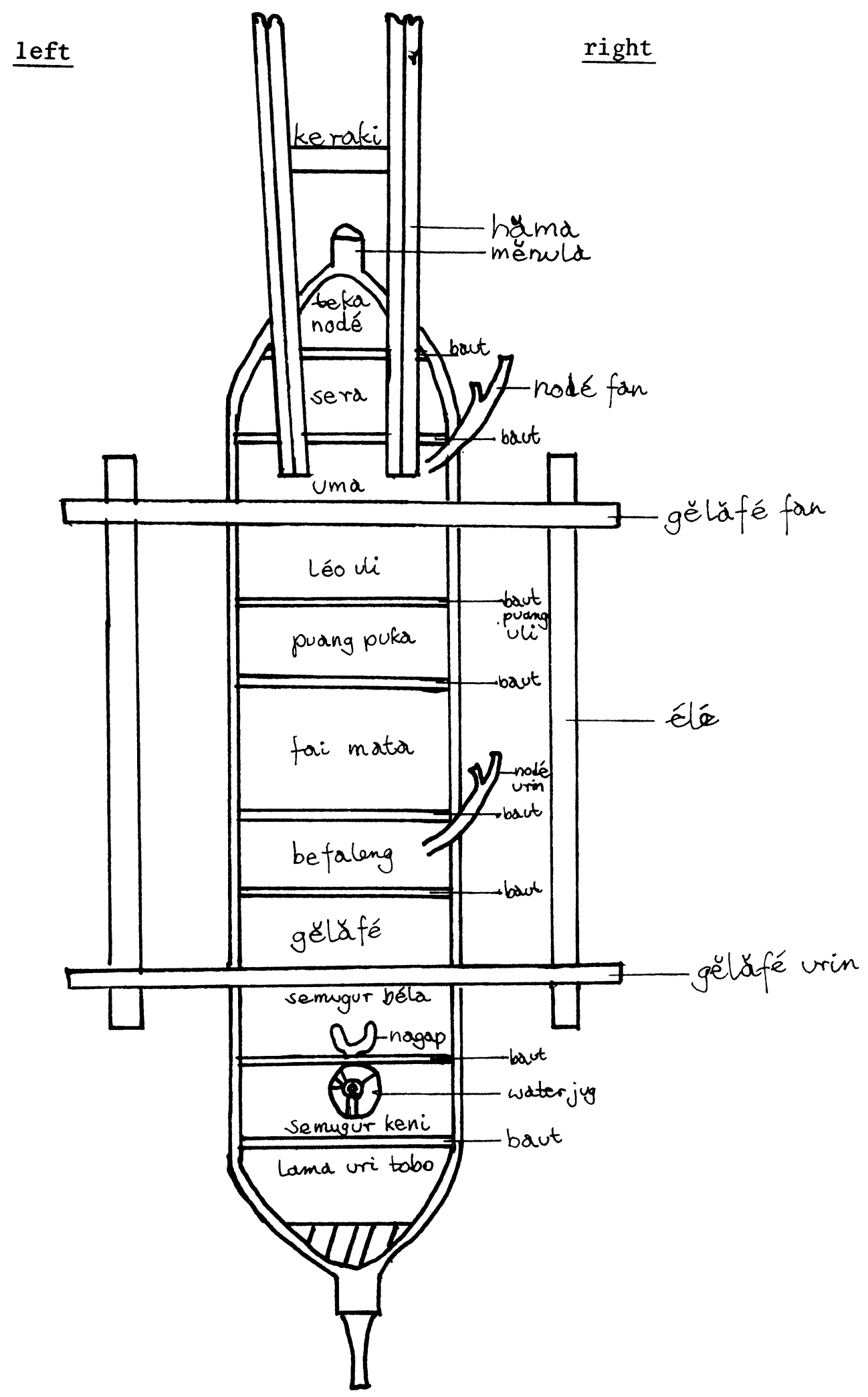

Figure 2. Inner Sections of the Pělédang. 
section of the hull is called mĕnula, a term which applies particularly to the upright extension of the prow (see Figure 1). According to Arndt 28 menula is the name of the large offering pole in eastern Adonara. He derives it from mula, meaning "to place," "to plant," "to set up."29 This piece, which would correspond to the figurehead on a European ship, is regarded as the head of the vessel and, when the boat is in its shed, the menula is covered with a special lontar-leaf sheath.

Several boats have eyes painted on the bow. Koening has found that the use of eyes or faces painted on the bow of a boat serving as a means of protection and vigilance is spread throughout the whole of ancient shipping. ${ }^{30}$ The outriggers of Bali, to give an example near Lembata, also have faces. ${ }^{3} 1$

In addition to these eyes on the bow there are a pair on the menula, that is, on the upright extension of the prow. If the reader will refer to Figure 3 , he will see that in the center of the edge between the top surface and the inner face of the menula there is carved a fingernail-shaped groove, called the féfan and representing a mouth. Another such groove is carved at the bottom of the inner face. Finally, the mĕnula has two eyes, made by boring a hole diagonally from the right face near the top of the menula to the inside face. As a result of this, the menula has both eyes on the right side, rather like a flounder.

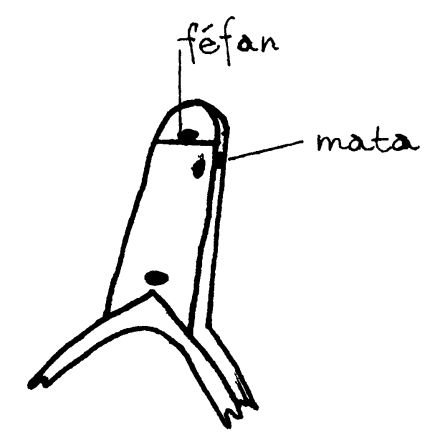

mata: the eyes.

fefan: a shallow groove, representing the mouth.

Figure 3. The Mĕnula.

28. Paul Arndt, Grammatik der Solor-Sprache (Ende, Flores: Arnoldus-Drukkerij, 1937), p. 11 .

29. H. H. O. Leemker, "Woordenlijstje van de Soloreesche Taal," Tijdschrift voor Indische Taal-, Land- en Volkenkunde, XXXVI (1893), p. 447.

30. Otto Koening, Kultur und Verhaltens-forschung: Einführung in die Kulturethologie (München: Deutscher Taschenbuch Verlag, 1970), pp. 200-204.

31. Cf. Miguel Covarrubias, Island of Bali (New York: Knopf, 1937), p. 12 and the second plate following p. 405 . 
In general it is to be noted that the boat is sharply divided into right and left. The harpoon rack lies on the right side (this is, of course, for most men only convenient), the drain hole must be on the right side, and this pair of eyes are found on the right. When building a boat, the villagers start in the center on the right side. Despite a necessarily very strong axial symmetry, the boat displays an asymmetric symbolic superiority of its right side.

Whenever the fishermen catch a ray, they are supposed to take the brain and feed it to the boat. This is done at the two grooves on the menula, the base of the lance pole of the type used for ray and of the lance pole used for porpoise. Further, the brain is offered to the forward support for the outriggers, the right one first, near the hul1; to the iron lance-point of the type used for ray; to the bindings fastening the loop on the end of the line used for ray (1éo); to a line drawn down the inside of the hull (téna kepurn) in the center of the section called fai mata, first on the right side, then on the left. Additional points are the aft support for the outriggers in the same spots as for the forward support; the base and front side of the rack which holds the upper ends of the masts when not in use; and the base on the front side of the decorated stern piece (madi). 32

There are two points to be made about this custom. First it is noteworthy that this is done only in the case where ray is caught. Not even whale requires it. The rope used for harpooning ray is set apart in the special care which it receives during the off-season and in the fact that when a new one is made, there must be a ceremony and feast in which a dog, goat or pig will be offered. The flesh of the ray is regarded as very fine, and this fact may have something to do with its special ceremonial importance, but we can be sure that there is more to the question.

The second matter is that the various places where the brain is fed to the boat may very well be compared to joint marks or points of access for spiritual force. Each year before the fishermen go to sea for the first time, they are supposed to cut the mouth of a living chicken and asperse its blood on the same spots, and this is also done when the léo, the line for ray, is changed. An argument of this sort has been made regarding the culture of Kédang, ${ }^{3} 3$ where I think the quintessential fact in their representation of being lies in an opposition between segments and alternating points of transition (1ike joints of a body) where spiritual essence may enter or leave. A demonstration for Lamalerap would require more facts than I now have and a comprehensive structural analysis of the sort which has been provided for their neighbors in Kédang.

IV

There is a lineage, Lama Nudek, allied to the clan Beliko Lolo and now almost extinct, which has traditional responsibility for building the boats and clan temples. Each clan has its own boat builders, so it may be that this clan was assigned a ceremonial position of leadership in the construction, but never an exclusive monopoly on the actual labor.

32. See Vatter, Ata Kiwan, plates 41,2 .

33. Barnes, Kédang. 
If a boat is to be built then this clan must take its tools to the clan temple of the clan building it. These are then placed on the fato bani, an altar stone lying on the balai or bamboo platform in the temple at the right post (rié fana). These tools would then be aspersed with chicken blood and afterwards taken to the beach for starting the work on the boat.

Before the influence of the missionaries became decisive, it seems that the villagers would hold a feast (including many chicken) on the night before laying the three pieces forming the keel. Then when the lowest plank of the hull was fitted, there would be a feast consisting of one or two goats. Another, similar feast would be held for the fitting of each of the other major parts of the hull. Today this is simplified, and they have a single feast when the larger planks have all been fitted.

Finally when the boat is finished and ready for launching, there is a large festival, lasting, according to Vatter, for three days. Vatter says:

Early in the morning, it is pulled out of the boathouse and once more carefully examined in all its parts, each mortise, each binding is tested. Then some goats or pigs are sacrificed; their blood is smeared on certain parts of the boat, especially the bow and the harpooning platform, and additionally the tools used in the construction. Moreover, they give the pledang itself, in which they see a sort of living being, meat and rice "to eat." Only then is it ready and seaworthy; however, it is not yet let into the water on this first day, but is brought back into its shed. After sundown, the whole village comes together for a feast; throughout the night there is singing and dancing. 34

I was told that the children must climb into the boat and there eat the chicken killed at this time, while other animals are eaten outside. Following the feast there is a night in which the boat is guarded from evil spirits by the craftsmen and others (this evening is called tia-balé téna). The workmen are called ata mola, the same name as that for the priest (elsewhere in Lamaholot called molang). This shows that they are thought to have priest-like powers, and these powers lie in their ability to bring life or spirit into being (the boat). This night of guarding further underlines that it is a question of giving some being life, for it is identical to the night of guarding when building the temple or, in East Flores, that preceding the planting of rice.35 After the evening meal on this night, a large tray of rice is carried to the four doors of the village--a procedure also observed when constructing a clan temple. A portion of the rice is dropped on the ground at each door, and some of it is strewn along the ground as the celebrants walk from door to door. The first door $v$ isited is the main door in the east, the bafa lofé béla; the second is the bafa lofé Zéfoléin, at the foot of the village. The third is the bafa Zofé méi Zaran, or the door of the road of blood. Formerly if an enemy from the Padji region in Labala were killed, he could not be brought into the village through the main door, but only through this special door in the west. (In this connection it should be noted that the back door of the temple is called the fai laran or the road of water and water may be brought in only through this door.) The

34. Ata Kiwan, p. 203.

35. Ibid., p. 110 . 
fourth door is called the ika kotă or fish head(s), where the skulls of fish or whale killed in the hunt are placed.

Vatter says that on the day following this night of feasting and guarding, the boat is taken out into the water and rowed a distance out to sea. There the crew lie down in the bottom of the boat and pretend to sleep. The village is gathered at the beach and after a while someone shouts, "Hey, you out there, where do you come from?" The crew jump up and shout back that they come from Lapan-Batan or Sika on Flores, in other words the supposed origin of that particular clan. Following this the men practice throwing the harpoon and that evening there is another feast and dance:

Early on the third day, they sail with the new plédang to market at the village Nualela, some eight kilometers northeast of Lamalerap, and load it there with maize, sweet potatoes, bananas, tobacco, and sirih-pinang and decorate it with fresh branches. While returning to Lamalerap, it is shot at from the beach with arrows and finally stormed and robbed. The pretended battle is continued along the coast until at nightfall all the villagers unite again for a feast and dancing. In this ceremony, the memory of an historical event, the landing and conquest of a plédang from Lapan-Batan or Flores, is doubtlessly kept alive. ${ }^{36}$

I was told that on this trip to the market the villagers would arrange beforehand to meet people from the mountain village of Lewuka there. They would then fill their boat as full as possible with fish, salt and so on and take it to the market. The people of Lewuka would bring an abundance of vegetables, rice, maize, cassava, etc. This would all be exchanged against what was brought in the boat without regard to relative value. When they returned to Lamalerap there would be a great scramble for the goods; presumably this would be part of the pretended battle Vatter describes. This trip is called groi téna, and both at the market and when returning everyone sprinkles each other with water--a common practice in this area at large festivals, especially when more than one village is involved. When they return, the tools must be offered an animal to eat before the boat can be taken out on a hunt.

When they take the new boat into the water for the first time and also when it is first taken to sea each year, they put pieces of cloth in the cracks all along the outer hull on both sides, and two 1 arger pieces on both sides of the mernula. These pieces, called presa, are all supposed to be white, but, I was told, are actually often of various colors, presumably because sufficient white cloth is not available Before taking the boat down to sea, they hold a baby pig to the prow and squeeze its throat to make it squeal. This is done so that they may get whale; if they did not do it, they would never get any. The pig is then struggled for by those present, and eventually goes to the strongest. ${ }^{3}$ It seems also that if they go for a period without any luck at sea, among the remedies they may resort to is to put ginger on the spots of the boat that are usually aspersed with blood or, now,

36. Ibid., pp. 203-4 .

37. This institution is to be interpreted in terms of the ceremonial role aggression has in Lamaholot culture, about which I have little information from Lamalerap, but which achieves a very marked place in East Flores. 
holy water. This would probably serve to make the boat more aggressive.

V

There have been several, usually obscurely placed, notices of the whaling industry of Lamalerap and Lamakera; but they are all very short and in some particulars often inaccurate, and we still lack a detailed account and integral treatment such as we should hope someday to have. The earliest report. which I have been able to find of whaling in this area comes from early in the last century in a book by the French traveler de Rienzi, 38 who remarked that the inahbitants of Solor are excellent seamen, enriching themselves by trade in whale oil, ambergris and wax. "On its coast, they hunt the noord-kaper, a species of whale whole fat gives oil and whose bladder appears to contain the precious ambergris." This scant report is accurate so far as it goes, though de Rienzi was unaware that only one Solor village hunted whales (and quite wrongly reported that the island contained kangaroos). Lamakera is first identified in this connection in a report of 1849,39 which despite some possible errors provides a useful, and our first, description of the hunt. Lamalerap is first briefly mentioned as a whalehunting village two years 1 ater by Baron van Lynden. 40 The first photograph of a whaling boat is found in two articles by Weber, 41 along with additional information about the industry.

The first of Weber's articles is notable for the hypothesis that the villagers learned the whale-hunt from American and English whalers. There seems to be no evidence in support of this theory, but nonetheless it may perhaps not be immediately dismissed. Whaling vessels did visit the area, as Melville testifies in mentioning the Timor (or Ombai) Straits and the nearby island of Ombay, now known as Alor. Ten Kate 42 even attributes the shyness of the women of the villages Trong and Lamahala on the south coast of Adonara to unpleasant memories of English whalers.

Several reports of Lamalerap, including occasional allusions to whaling, are found in the mission journal Berichten uit Nederlandsch oost-Indië voor de Leden van den Sint-Claverbond during the last decades of the nineteenth and ear1y in this century. The most useful of these is a description by Engbers, from which the following is excerpted:

38. G. L. Domeny de Rienzi, Océanie ou cinquième partie du monde, 5 vols: (Paris: Firmin Didot Frères, 1836-37), I, p. 205.

39. "Walvischvangst der Solorezen"; "Whale Fishing of the Solorese," Journal of the Indian Archipelago and Eastern Asia, IV (1850), pp. 766-67.

40. D.W. C. Baron van Lynden, "Bijdrage tot de Kennis van Solor, Allor, Rotti, Savoe en omliggende Eilanden, Getrokken uit een Verslag van de Residentie Timor," Natuurkundig Tijdschrift voor Nederlandsch-Indië, II (1851), pp. 321-22.

41. Max Weber, "Iets over Walvischvangst" and Siboga-Expedie I: Introduction et description de 1'expedition (Leiden: Bril1, 1902).

42. Ten Kate, "Verslag eener Reis," p. 243. 
Al1 [the inhabitants] live from the sea. They hunt almost exclusively large fish and seamonsters, especially whales, which are very frequent there. Each morning a fleet of ten to twelve large outrigger proas, called plédangs, go out to sea for this purpose. Each proa is manned by about twelve oarsmen. A sort of ladder, which is several meters long and slants up with a small incline, sticks out in front of the proa; and on the front of the ladder stands a man who is armed with a harpoon: i.e., a long bamboo pole with an iron barbed hook on the end. The harpoon is tied fast to a long line, the other end of which is fastened to the proa in such a way that it may be easily paid out. Should someone spy any kind of seamonster, they then steer gently in that direction and try to approach the brute. At a favorable moment, the man throws or darts his harpoon and then himself jumps into the water. If the throw is effective and if the animal which is struck is a whale, then all the oarsmen also jump into the sea. The other plêdangs then first pick up the swimming men and afterwards begin the chase. The oarsmen know their work and the proas shoot ahead as though driven by a tempest after the monster which pulls the heavy proa with it. Before long the beast tires, slows and is overtaken by the oarsmen. The harpooners wound it again and again until, finally completely worn out, it can no longer escape and is finished off.

Then the men jump out of the plédangs onto the dead animal, together hew out pieces and load them on their proas. Sometimes, however, it is pulled intact to land and divided up there. I do not believe that anywhere else in our East Indies are there natives who live so exclusively from large-scale fishing as the people of Lamalera and nowhere have I seen native fishermen with such daring and fearlessness. ${ }^{43}$

From my experience I can remark about Engbers' report that the crew does not usually jump into the water after harpooning a whale; and $I$ assume they would only leave the boat if it were endangered by the animal. Individuals often jump into the water and cut on the exhausted animal when trying to kill it, but they would only cut the carcass up at sea in the exceptional case where it was not possible to pull it to shore. The harpooner, however, does jump, adding his weight to the force of the thrust. He grabs an outrigger as the boat shoots past, and pulls himself back aboard.

An anonymous publication of 1910 in the Tijdschrift voor Economische Geographie corrects a previous report in that journal that there is no native hunting of whale. in Indonesia and quotes the above excerpt from Engbers and gives a summary of Weber. It overlooks, as does Weber, the earliest notices by de Rienzi and the anonymous publication of 1849. In the next year the official report of Captain Beckering appeared which contains two pages on whaling in Lamalerap. 44 The last and most extensive account of Lamalerap and its whaling industry is given by Ernst Vatter 45 from his four days there in 1929 . He had the misfortune that no whale were sighted while he was in the village so that he had no opportunity to accompany the hunt. His report is nevertheless quite useful. A view of the village is given in his Plate 4l, which also contains good photographs of the boat.

43. Engbers, "Walvischvangers."

44. Beckering, "Beschrijving," pp. 194-95.

45. Ata Kiwan, pp. 201-7. 
At this point I will turn to a description of the hunt as I experienced it. Though there are some points of possible disagreement with the earlier reports, none of these are of any great moment, and we can be fairly sure that it is still conducted today very much as it was a century and a half ago when Europeans first began to be aware of it. After this long period, I think I am the first European to witness the capture of whale; I am certainly the first to do so from the vantage point of one of the vessels involved, and the following account and the accompanying photographs are the first published results of such direct observations.

During the season when the fleet puts out after whale and other large mammals and fish, the boats are usually drawn down the beach and launched in the surf about sunrise (Photograph I). They then sail directly out to sea in search of game until about the middle of the day, when, if they have had no luck, they turn back. They do not like to be on the open sea at night, so if in the early afternoon they are very far out, they will no longer give chase, even if the opportunity presents itself, but turn back toward shore.

The day I went out with them proved to be a very good one in what had otherwise been a very poor season. Delayed by rain, we were the last of thirteen boats to put out. Using logs as rollers under the boat, they pulled the boat down to the water, and then rowed it out beyond the breakers. When the boat was past the rough water, the entirely Catholic crew stopped for a moment to say a communal pater Noster and then put up the sail.

Though widely scattered across the sea, the boats all sailed as a fleet and in the same general direction. For several hours then, there was little to do but to keep a look-out. For this purpose most of the crew stood in the boat (Photograph II), each keeping an eye on a different section of the horizon. Naturally, they also kept close watch on the other boats to see if they showed any signs of having spotted game. The oars were not used during this time, and the boat moved ahead only under the force of its sail. The long wait was interrupted only once when another boat spotted a manta ray and turned to chase it back through the fleet.

What appeared to an inexperienced observer as a fairly futile day of fishing took on new life when the fleet sailed into a school of porpoise, and suddenly several boats were occupied in different areas with an earnest chase (Photographs III and IV). We were ourselves hard after a shoal of the animals, when one of our crew, with what would seem remarkable presence of mind, noticed that a boat far on the other side of the fleet had struck a whale. We immediately forgot the porpoise and turned toward the whale. It seems that every boat in the fleet had seen at almost the same time that one of them had speared a whale, and they then converged, with all the speed the sails and oars could produce, on the boat and injured whale.

When the game changes from porpoise or ray to whale, the nature of the hunt is drastically altered, and the crew mark this transformation by pausing just before entering the fray for preparation. This includes lowering the sail, which otherwise would be just an encumbrance and a danger to the crew. Everyone takes this occasion to relieve himself over the side of the boat, and then there is a second communal Pater Noster. 

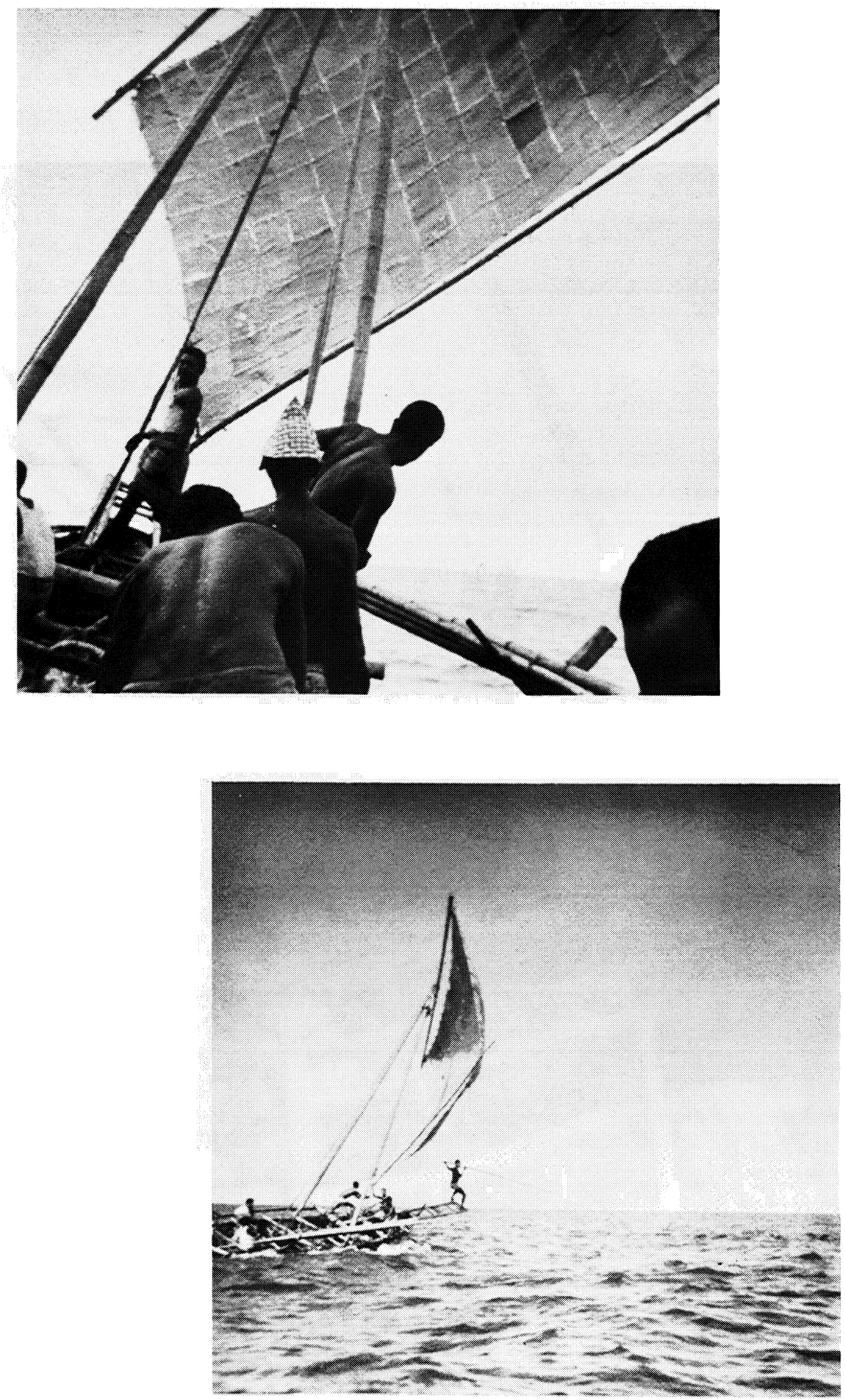

Photographs II and III 


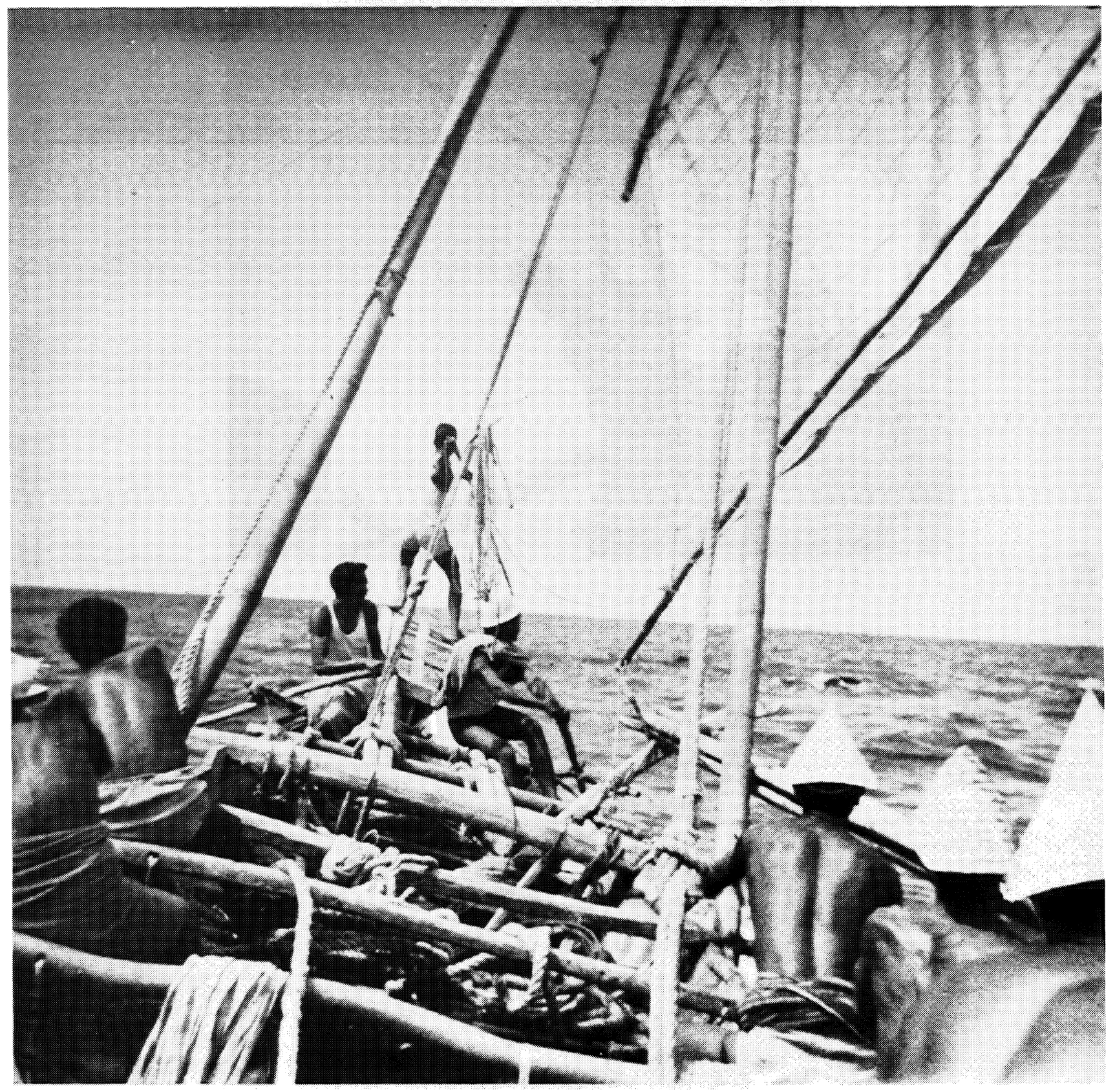

Photograph IV 
When one of their fellows is wounded, whale draw around it, and the best chance to strike another is offered by sailing into this milling group. On this principle, the widespread fleet formed with what seemed to me remarkable suddenness a congested pack at the center of which was a boat racing without control behind a maddened whale. Just at the moment that we found ourselves in the middle of this tight group, the whale turned in our direction. The boat to which it was attached collected two more in being pulled around, and this helpless mass then came directly on top of us, breaking in a plank at the side. The whale was already bleeding profusely and my memory of this moment is made up of images of the red clouds in the sea around us, the heaving mass of whales on all sides, the harpooners, harpoon platforms and above all the razor-sharp harpoons themselves which kept passing overhead, and the threat of further collision continually reappearing in an always new quarter.

My point of observation was naturally that of a passive and inexperienced outsider. To the crewmen this was an everyday matter over which, despite appearances, they never lost çontrol, and we were almost immediately freed from the other boats and had ourselves a whale. This does not mean that we were in no danger of finding ourselves suddenly in a similar situation, for we, too, became parties to an uncontrolled race behind a maddened whale. Boats which were rushing full speed after another objective suddenly found us being pulled across their bows.

In an exciting few minutes the two boats were pulled by their whales back and forth across each other's paths, while the other boats tried to set harpoons into the whale and while the crew attempted to place hooks into them to draw them close to the side of the boat. When we were finally secured to ours, the boat began to heave with the whale's throws and shipped large quantities of water and blood. The prime concern at this moment was to kill the whale as soon as possible, and as it became more exhausted it was possible to draw it full length against the side of the boat. It was tied fast and the crew then lined up along this side and started hacking on the whale with their long cutting knives. Everyone cuts in a different place, but this has no purpose other than to finish the whale. Melville says that when cutting the whale, they must occasionally stop to hone the cutting spades, which must be kept as sharp as possible. The same is true of the knives used in Lamalerap and each member of the crew keeps a sharpening stone near his place in the boat. The first to cut through the blubber cuts out some flesh and baits hooks for shark which can be expected to be drawn to the scene. The sharks notwithstanding, some of the crewmen jump into the water to dive under the whale and cut from underneath. When one of the men got his knife into the whale's heart, his spout sent up a shower of blood.

This ended the excitement, and all that remained was to secure the hooks and to begin towing the whale to shore. Four boats had managed to set a harpoon in our whale at one time or another, and although they did not participate in killing it, they had a claim in its division. We then formed a convoy by tieing the four boats in a row and sailed for home. The fleet's catch for the day was two whales, six shark and two manta ray. One boat lost its harpooning platform, which meant it would be out of use for several weeks, and ours lost a plank in the side. The two whale were just infants and not as long as the boat. Both were sperm shale, the largest variety which is hunted in Lamalerap. 
Vatter 46 says that they attempt to kill only whales of this variety which are not over nine or ten meters in length, thus, those which are not longer than the boat. I was told that they will attempt any whale, but if there is a choice they prefer the smaller and weaker ones. This was demonstrated by the hunt I observed, for they harpooned only the small ones and let the mother go.

Although skill and experience allows them to do calmly and safely things which are full of jeopardy, they are not unaware of the dangers of the hunt nor are they insensitive to its thrill. The chase of whale is set apart in a number of ways from that of other game. It will be remembered that when whale are sighted, before going into the attack they first stop to relieve themselves, take down the sail and say a prayer. When they chase other game such as ray or porpoise, they leave their sail up. For whale, they always take it down--a procedure that is made imperative by the strength of the animal and the frequent colIisions with other boats. Once they have struck a whale they may not smoke, drink or carry on conversation until the whale is dead. They are not prohibited to speak about the matter at hand, and there was a great deal of rather subdued shouting and talking while we were killing them. It is noteworthy that this is hardly done in a boisterous manner and that even the shouting is in a more restrained tone than is normal. These prohibitions were said (in Bahasa Indonesia) to be pemali, that is they are religious restrictions. In fact, they are just what one would expect in a similar tense and perilous situation, but they have, nevertheless, a symbolic significance in their culture. When striking whale, as opposed to other game, they may not address each other by name, but must use only bapa (the common term for addressing a male in Lamaholot). One may not use the word for the sperm whale, kotan kĕléma, but must always refer to it as "the fish," ikan. There are also special terms for the parts, tools and operations in the boat which must be employed instead of the more common expressions. Such a custom of using special terms during the hunt (on land) is found in other societies in Indonesia. ${ }^{47}$ Here though, it singles out the whale, and probably indicates that the passage of its life is regarded as of great significance for them. The whale may very well be comparable to rice in the religions of other Indonesian peoples.

\section{I}

Life in the village of Lamalerap has many features of great interest to an outsider. Perhaps what first attracts attention is the

46. Ibid., p. 202 .

47. For discussion of special vocabularies of this type see $J$. Gonda, "The Javanese vocabulary of courtesy," Lingua, I, no. 3 (1948), especially pp. $337 \mathrm{f}$., and works cited there; C. Snouck Hurgronje, De Atjèhers, 2 vols. (Batavia: Landsdrukkerij, 1893), I, pp. 303-4; and more widely, Arnold van Gennep, "Essai d'une théorie des langues spéciales," Revue des études ethnographiques et sociologiques, I (1908), pp. 327-32. Gonda, "Javanese vocabulary," p. 338, says, "It would appear to me that the tendency to avoid terms denoting 'powerful' events, beings, etc. is peculiar to man in general." Van Gennep, "Essay," p. 331, relates the use of special languages to his famous structural analysis of rites of passage and remarks on p. 333, "la langue spéciale est un phénomène normal." Snouck Hurgronje reports a special vocabulary for fishermen in Atjèh and refers to similar customs during hunting or at sea on Java. 
sheer adventure and daring of the fishery. But there is in addition the example of an economy blending ancient crafts with newly learned, educated occupations and a culture which seems to have met the heavy pressures for change from Europeans and still retained a characteristic sense for their traditions. For the anthropologist, their social organization offers an attractive opportunity for comparative study of the theme of prescriptive alliance among closely related peoples.48 A total structural analysis--which is most feasible in prescriptive societies and which it may one day be possible to provide--would put topics mentioned here only in passing in a larger and clearer context; and the fishery, which has best retained Lamalerap tradition and which was always the center of their interest, is the place to begin.

48. Barnes, Kédang. 